\title{
Evaluation of Air Pollution Tolerance Index and Anticipated Performance Index of Plants and their Role in Development of Green Belt along National Highway-22
}

\author{
Kashish Walia*, R.K. Aggrawal and S.K. Bhardwaj \\ Department of Environmental Science, Dr. Y S Parmar University of Horticulture and \\ Forestry, Nauni - 173230 (Solan), India \\ *Corresponding author
}

A B S T R A C T

\begin{tabular}{|l|}
\hline Ke y w o r d s \\
Bio indicators, \\
Biochemical \\
parameters, APTI, API \\
\hline Article Info \\
\hline Accepted: \\
18 February 2019 \\
Available Online: \\
10 March 2019 \\
\hline
\end{tabular}

Plants play an important role in mitigating air pollution. In such a scenario where problems due to air pollution are faced worldwide screening of sensitive and tolerant plants which acts as a bio indicator and sinks for air pollution is extremely significant. Therefore, present study was designed to evaluate the Air Pollution Tolerance Index (APTI) of six roadside plant species namely Cassia fistula, Grevillea robusta, Grewia optiva, Leucaena leucocephela, Toona ciliate and Woodfordia floribunda growing alongside a selected stretch of National Highway 22 (Datiyar to Solan) in Himachal Pradesh, India. The Anticipated Performance Index (API) of these plant species was also calculated by considering their APTI values with biological and socio-economic characters (plant height, canopy structure, type of plant, laminar characteristics, texture, hardiness and economic value). The study indicated that Cassia fistula with highest APTI value of 23.5 and highest API score is best for green belt development.

\section{Introduction}

The blooming growth in Indian economy in terms of industrialization, urbanization and modernization has lead to increase in various economic activities, where road development has become an integral part, ameliorating the efficient connectivity, financial and social welfare of the people. But such activities go hand in hand causing damage to the natural assets of the environment to a greater or a lesser extent by disturbing the existing ecosystem. Air pollution due to expansion and vehicular emissions has become one of the most serious problems and has resulted in huge threat to both the environment and the health of living organisms like plants, animals and humans (Kaur and Nagpal, 2017). The combustion activities also adds toxic gases like SOX, NOX, CO and particulate matter into the air which includes soot particles as well as smaller quantities of toxic metals, organic molecules and radioactive isotopes (Bhattacharya et al., 2013). Plants growing along the roadsides get affected at the maximum as they are the primary recipients to different air pollutants and show varied levels of tolerance and sensitivity and also plays an important role in monitoring and maintaining the ecological balance by actively 
participating in the cycling of nutrients and gases like carbon dioxide and oxygen (Mahecha et al., 2013). The air pollutant once released into the atmosphere cannot be traced or identified by any device chemically or mechanically, only plants can absorb and metabolise these pollutants from the atmosphere. Therefore, the role of plants in assessing the air pollution is being increasingly recognised and is used in evaluating the Air Pollution Tolerance Index which is a species dependent plant attribute and expresses the inherent ability of plant to encounter stress arising from air pollution and helps in identifying the tolerance levels of plant species based on biochemical parameters viz. ascorbic acid, $\mathrm{pH}$ of leaf extract, total chlorophyll and relative water content (Shannigrahi et al., 2003).

Plants with higher APTI value are tolerant to air pollution and can be used to mitigate air pollution while those with low index value show less tolerance and can be used to signify levels of air pollution (Madan and Chauhan, 2015). The APTI index evaluates the effect of pollutants only on biochemical parameters, but in order to combat air pollution using green belt development, some biological and socioeconomic characteristics are also considered and used to develop the anticipated performance index (API) (Govindaraju et al., 2012).

The expansion of NH-22 from Timber-Trail resort in Datiyar to Solan has deteriorated the air quality as being perceived by urban dwellers because of developmental activity and large vehicular density in the area, as the road stretch being a part of tourist route and connecting the cities of Chandigarh, Ambala, Kalka, Parwanoo and Shimla the state capital city of Himachal Pradesh carries a significant heavy traffic to and fro from Shimla and other parts of the State. Hence all these activities have highly deteoriated the air quality.
Therefore, the present study can help in screening out the air pollution tolerant plant species and calculating their anticipated performance index (API) which can be used as an indicator to assess the capability of predominant species for cleaning up of the atmospheric pollutants and in development of the green belt along the National Highway.

\section{Materials and Methods}

\section{Study area}

The entire study area extends on National Highway-22 which connects Firozepur, Punjab in the North end to Shipki La, SinoIndian border to the South end. The study area covers a part of NH-22 of Solan district from Timber-Trail resort in Datiyar to Solan covering a distance of about $40 \mathrm{kms}$. The Highway lies between North latitude of $30^{\circ} 44^{\prime} 53^{\prime \prime}$ to $31^{\circ} 22^{\prime} 01^{\prime \prime}$ and East longitude of $76^{\circ} 36^{\prime} 10^{\prime \prime}$ to $77^{\circ} 15^{\prime} 14^{\prime \prime}$. The study area has high vehicular density as it is a major part of tourist route connecting the cities of Chandigarh, Ambala, Kalka, Parwanoo and Shimla, the capital city of Himachal Pradesh.

\section{Survey of the study area}

In order to study the distribution of plants growing alongside the national highway and to screen out the most tolerant plants species to pollution a detail survey of National Highway22 was conducted from Datiyar to Solan. The vegetation distribution study was carried by using quadrat method and in order to maintain the uniformity, plants of same age and spread growing at iso-ecological conditions were selected for the study.

The commonly occurring plant species identified and selected were Cassia fistula, Grevillea robusta, Grewia optiva, Leucaena leucocephela, Toona ciliate and Woodfordia floribunda. 


\section{Experimental details}

In order to conduct the present study the National Highway 22 was divided into four uniform segments based on distance and each segment was considered as one replication. The six commonly growing plant species viz. Cassia fistula, Grevillea robusta, Grewia optiva, Leucaena leucocephela, Toona ciliate and Woodfordia floribunda were selected from both the sides of the National Highway. In total there were 24 treatment combinations (6 x 4) which were replicated four times under factorial Randomized Block Design. The data for the two sides (left and right) of the national highway was clubbed for statistical analysis and the results were statistically analyzed and interpreted by using Statistical Package Software version 21 .

\section{Sample collection and analysis}

To assess the APTI based on the four parameters namely leaf ascorbic acid, leaf extract $\mathrm{pH}$, total chlorophyll, and relative water content fully matured leaves of selected plant species were collected randomly from both sides of the road in the morning hours at almost same diameter at breast height (DBH). The leaf samples were then transported to the laboratory in ice - box and washed with normal water and then with $0.1 \mathrm{~N} \mathrm{HCL}$ followed by washing with distilled water. Further, the analysis of physiological and biochemical parameters of leaf samples were carried out as per the standard procedures as mentioned below:

\section{Analysis of biochemical parameter}

\section{Ascorbic acid}

To estimate leaf ascorbic acid content of selected plant species $10 \mathrm{~g}$ of the sample was taken. The sample was homogenized in metaphosphoric acid (3\%) and filtered. The volume of the filtrate was made to $100 \mathrm{ml}$ by metaphosphoric acid (3\%). The aliquot measuring $10 \mathrm{ml}$ was taken and titrated against standardized dye to an end point of pink colour as per the standard procedure outlined by Association of Official Agricultural Chemists (1980). The ascorbic acid content was expressed in milligrams per grams $\left(\mathrm{mg} \mathrm{g}^{-1}\right)$.

Dye factor $x$ Titre reading $x$ Volume made $\times 100$

Ascorbic acid $(\mathrm{mg} / 100 \mathrm{~g})=$

Weight of leaves taken $x$ Volume taken for estimation

\section{Leaf extract pH}

Leaf extract $\mathrm{pH}$ of the sample was analyzed by the method suggested by Barrs and Weatherly (1962). Fresh leaf sample (10g) was homogenized using deionised water $(50 \mathrm{ml})$ and the supernatant obtained after centrifugation was collected for the determination of $\mathrm{pH}$ using a digital $\mathrm{pH}$ meter.

\section{Total chlorophyll}

For the estimation of total chlorophyll content of the leaves, $10 \mathrm{mg}$ of the leaf sample was homogenized with $7 \mathrm{ml}$ dimethyl-sulphoxide and was kept in oven at a temperature of 60$65^{\circ} \mathrm{C}$ for $30-35$ mins.

The samples were filtered and volume was made to $25 \mathrm{ml}$ by dimethyl-sulphoxide. The absorbance was measured at $663 \mathrm{~nm}$ and $645 \mathrm{~nm}$ in spectrophotometer and chlorophyll was estimated using the following equation given by Hiscox and Istaelstam (1979)

$$
20.2 \text { A645 + 8.02 A663 }
$$

Total chlorophyll $(\mathrm{mg} g-1)=----------\mathrm{x} \mathrm{V}$

$$
\mathrm{a} \times 1000 \times \mathrm{w}
$$

Where; 
$\mathrm{V}$ is volume of extract made

a is length of light path in cell (usually $1 \mathrm{~cm}$ )

$\mathrm{W}$ is weight of sample

$\mathrm{A}_{645}$ is absorbance at $645 \mathrm{~nm}$

$\mathrm{A}_{663}$ is absorbance at $663 \mathrm{~nm}$

\section{Relative water content}

Relative water content of the samples was estimated using the method proposed by Singh (1977) and was computed by using following equation

$\mathrm{RWC}=\frac{(\mathrm{FW}-\mathrm{DW})}{(\mathrm{TW}-\mathrm{DW})}$

Where;

RWC is relative water content (\%)

FW is fresh weight of leaf sample

DW is dry weight of leaf sample

TW is turgid weight of leaf sample

\section{Air pollution tolerance index (APTI)}

The Air pollution tolerance index based on leaf biochemical parameters was computed by using the following formulae given by Singh and Rao (1983).

$\mathrm{APTI}=\frac{[\mathrm{A}(\mathrm{T}+\mathrm{P})]+\mathrm{R}}{10}$

Where;

A is ascorbic acid $\left(\mathrm{mg} \mathrm{g}^{-1}\right)$ of leaf sample

$\mathrm{T}$ is total chlorophyll $\left(\mathrm{mg} \mathrm{g}^{-1}\right)$ of leaf sample

$\mathrm{P}$ is leaf extract $\mathrm{pH}$ of leaf sample

$\mathrm{R}$ is relative water content (\%) of leaf sample

\section{Anticipated Performance Index}

By combining the resultant APTI values with some relevant biological and socioeconomic characters (plant height, canopy structure, plant size texture, hardness and economic value) the API was calculated for different plant species. Based on these characters, different grades (+ or -) are allotted to plants. Different plants are scored according to their grades as per the procedure outlined by Mondal et al., (2011).

\section{Results and Discussion}

\section{Biochemical parameters}

\section{Leaf ascorbic acid content}

The different plant species growing along National Highway -22 were found to exhibit significant variations in leaf ascorbic acid content Fig.1. The ascorbic acid content of selected plant species varied from 2.85 to $10.22 \mathrm{mg} \mathrm{g}^{-1}$. Among the selected plant species the highest ascorbic acid content was recorded in Cassia fistula (10.22 $\mathrm{mg} \mathrm{g}^{-1}$ ). Whereas, lowest was observed in Grewiallia robusta $\left(2.85 \mathrm{mg} \mathrm{g}^{-1}\right)$. The order of ascorbic acid content in leaves of selected plant species was Cassia fistula (10.22 $\left.\mathrm{mg} \mathrm{g}^{-1}\right)>$ Leuceana leucocephala (9.58 $\left.\mathrm{mg} \mathrm{g}^{-1}\right)>$ Woodfordia fruticosa $\left(7.33 \mathrm{mg} \mathrm{g}^{-1}\right)>$ Toona ciliata $(5.26$ $\left.\mathrm{mg}^{-1}\right)>$ Grewia optiva $\left(5.18 \mathrm{mg} \mathrm{g}^{-1}\right)>$ Grewiallia robusta $\left(2.85 \mathrm{mg} \mathrm{g}^{-1}\right)$. Ascorbic acid is a natural antioxidant that influences the resistance of plants against adverse environmental conditions and helps in pollution tolerance (Subramani and Devaanandan, 2015). Different developmental activities and vehicular emissions leads to air pollution especially in areas with high traffic and higher commercial activities and enhances production of more antioxidants in response to stress conditions. The results are in conformity with the findings of Prajapati and Tripathi (2008). Higher ascorbic acid content in the leaves of Cassia fistula may probably be due to improvement in the defence mechanism of the plants which has been reported to be 
different for different plant species by (Chen et al., 2007). Trees under stress improve their ascorbic acid content to improve their capacity to fight against adverse conditions. The results are in line with the findings of Yannawar and Bhosle (2013) who have also reported higher ascorbic acid content in the leaves of the plants growing near roadside due to higher pollution stress

\section{Total chlorophyll content}

The leaf Chlorophyll content of the different plant species varied significantly from 9.18 mg $\mathrm{g}_{-}{ }^{1}$ to $1.36 \mathrm{mg} \mathrm{g}^{-1}$ along the National Highway 22 Fig.1. In the selected stretch, among the six selected plant species highest leaf chlorophyll content was recorded in Cassia fistula (9.18 mg g-1) whereas lowest was recorded Woodfordia fruticosa $(1.36 \mathrm{mg}$ $\left.\mathrm{g}^{-1}\right)$. The order of leaf chlorophyll content in the leaves of selected species was Cassia fistula > Leuceana leucocephala > Toona ciliata $>$ Grewiallia robusta $>$ Grewia optiva > Woodfordia fruticosa. The leaf Chlorophyll content of plants signifies its photosynthetic activity as well as the growth and development of biomass. The chlorophyll content varies from species to species and also with the pollution level as well as with other biotic and abiotic conditions (Begum and Harikrishna, 2010). Higher the chlorophyll contents higher the tolerance to pollution (Joshi et al., 1993).

The chlorophyll content in all the plants varied with the tolerance as well as sensitivity of the plant species to pollution load i.e. higher the sensitive nature of the plant species lower the chlorophyll content. These results are supported by the findings of Joshi et al., (1993). Further, automobile exhaust and other anthropogenic activities at traffic site are responsible for reduced concentration of chlorophyll. The variation in chlorophyll content in the leaves of selected plants species could be attributed to their inherent capacity to tolerate the pollution stress along roadside as well as due to vehicular pollution in the selected stretch of the National Highway. The results are in line with the findings of Ninave (2001). Higher the level of automobile pollution higher is the decrease in leaf chlorophyll content of plants near roadside (Mir, 2008).

\section{Leaf extract pH}

The different plant species along National Highway 22 were found to exhibit significant variations in leaf extract $\mathrm{pH}$ of selected plants species. Figure 1 indicates that leaf extract $\mathrm{pH}$ of different plant species along National Highway varied from 5.82 - 6.77. Among the selected species Cassia fistula was noticed to have maximum leaf extract $\mathrm{pH}$ of 6.77 . Whereas, minimum was observed in Grewiallia robusta (5.82). The order of leaf extract $\mathrm{pH}$ of selected plant species was Cassia fistula (6.77) followed by Leuceana leucocephala (6.46), Grewia optiva (6.33), Toona ciliata (6.20), Woodfordia fruticosa (5.85), Grewiallia robusta (5.82). The variations in leaf extract $\mathrm{pH}$ in selected plants along National Highway could be attributed due to the varied genetic composition of the plant species. Higher level leaf extract $\mathrm{pH}$ in Cassia fistula indicates the tolerance of plant under polluted conditions. The results are in line with (Gholami et al., 2016) who stated that the reduction in $\mathrm{pH}$ value is more in sensitive plants compared to those in tolerant plants. Further, lower value of leaf extract $\mathrm{pH}$ in selected plants species growing at traffic and commercial areas may be ascribed due to highest level of vehicular pollution and developmental activities in these areas. Similar results were also observed by Singare and Talpade (2013) who also reported that the leaf extract $\mathrm{pH}$ tend to decrease with the increase in pollution with respect to nonpolluted site. 
Table.1 Gradation of plant species based on air pollution tolerance index as well as morphological parameters and socio-economic importance

\begin{tabular}{|c|c|c|c|}
\hline \multicolumn{2}{|l|}{ Grading Character } & Pattern of assessment & Grade allotted \\
\hline \multirow[t]{5}{*}{ Tolerance } & APTI & $9.0-12.0$ & + \\
\hline & & $12.1-15.0$ & ++ \\
\hline & & $15.1-18.0$ & +++ \\
\hline & & $18.1-21.0$ & ++++ \\
\hline & & $21.1-24.0$ & +++++ \\
\hline \multirow{9}{*}{$\begin{array}{l}\text { Biological and } \\
\text { socio-economic }\end{array}$} & Plant habit & Small & - \\
\hline & & Medium & + \\
\hline & & Large & ++ \\
\hline & $\begin{array}{l}\text { Canopy } \\
\text { Structure }\end{array}$ & Sparse/irregular/globular & - \\
\hline & & Spreading crown/open/semi- & \\
\hline & & dense & + \\
\hline & & Spreading dense & ++ \\
\hline & Type of plant & Deciduous & - \\
\hline & & Evergreen & + \\
\hline \multirow[t]{9}{*}{ Laminar structure } & Leaf size & Small & - \\
\hline & & Medium & + \\
\hline & & Large & ++ \\
\hline & Texture & Smooth & - \\
\hline & & Coriaceous & + \\
\hline & Hardiness & Delineate & - \\
\hline & & Hardy & + \\
\hline & $\begin{array}{l}\text { Economic } \\
\text { value }\end{array}$ & Less than three uses & - \\
\hline & & Three or four uses & + \\
\hline
\end{tabular}

Table.2 Anticipated performance index (API) of plant species

\begin{tabular}{|c|c|c|}
\hline Grade & Score & Assessment category \\
\hline $\mathbf{0}$ & Up to 30 & Not recommendation for plantation \\
\hline $\mathbf{1}$ & $31-40$ & Very poor \\
\hline $\mathbf{2}$ & $41-50$ & Poor \\
\hline $\mathbf{3}$ & $51-60$ & Moderate \\
\hline $\mathbf{4}$ & $61-70$ & Good \\
\hline $\mathbf{5}$ & $71-80$ & Very good \\
\hline $\mathbf{6}$ & $81-90$ & Excellent \\
\hline $\mathbf{7}$ & $91-100$ & Best \\
\hline
\end{tabular}


Table.3 Evaluation of API of plant species based on their APTI values and some other biological and socio-economic characters

\begin{tabular}{|l|l|l|l|l|l|}
\hline Sr. No. & Plant species & Total grade allotted & $\%$ Score & API value & Assessment \\
\hline 1. & Woodfordia fruticosa & 3 & 18.75 & 0 & Not recommended \\
\hline 2. & Grewia optiva & 8 & 50.00 & 2 & Poor \\
\hline 3. & Toona ciliata & 10 & 62.50 & 4 & Good \\
\hline 4. & Greviallia robusta & 8 & 50.00 & 2 & Poor \\
\hline 5. & Leuceana leucocephela & 8 & 50.00 & 2 & Poor \\
\hline 6. & Cassia fistula & 10 & 62.50 & 4 & Good \\
\hline
\end{tabular}

Table.4 Assessment based on anticipated performance index of selected plant species

\begin{tabular}{|c|c|c|c|c|c|c|c|c|c|c|c|}
\hline \multirow[t]{2}{*}{ Plant species } & \multicolumn{4}{|c|}{ Assessment parameters } & \multicolumn{4}{|c|}{ laminar structure } & \multicolumn{3}{|c|}{ Grade alloted } \\
\hline & $\bar{z}$ & 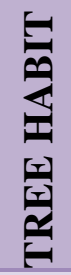 & 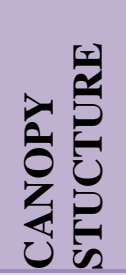 & 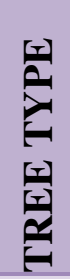 & $\frac{\sqrt[n]{2}}{\mathbf{N}}$ & 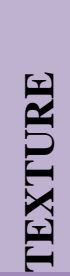 & 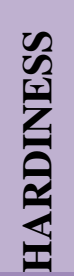 & 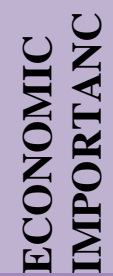 & 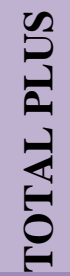 & 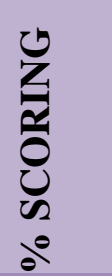 & $\frac{\sqrt{2}}{\frac{2}{6}}$ \\
\hline Woodfordia fruticosa & + & - & - & - & + & - & + & - & 3 & 18.75 & 0 \\
\hline Grewia optiva & + & + & + & - & + & + & + & ++ & 8 & 50.00 & 2 \\
\hline Toona ciliata & ++ & ++ & + & - & ++ & + & + & + & 10 & 62.50 & 4 \\
\hline Grewiallia robusta & + & ++ & + & + & ++ & - & + & - & 8 & 50.00 & 2 \\
\hline Leuceana leucocephela & +++ & + & - & - & ++ & - & - & ++ & 8 & 50.00 & 2 \\
\hline Cassia fistula & +++++ & + & - & + & ++ & - & - & + & 10 & 62.50 & 4 \\
\hline
\end{tabular}

Fig.1 Variations in the biochemical parameters and APTI values of selected plant species

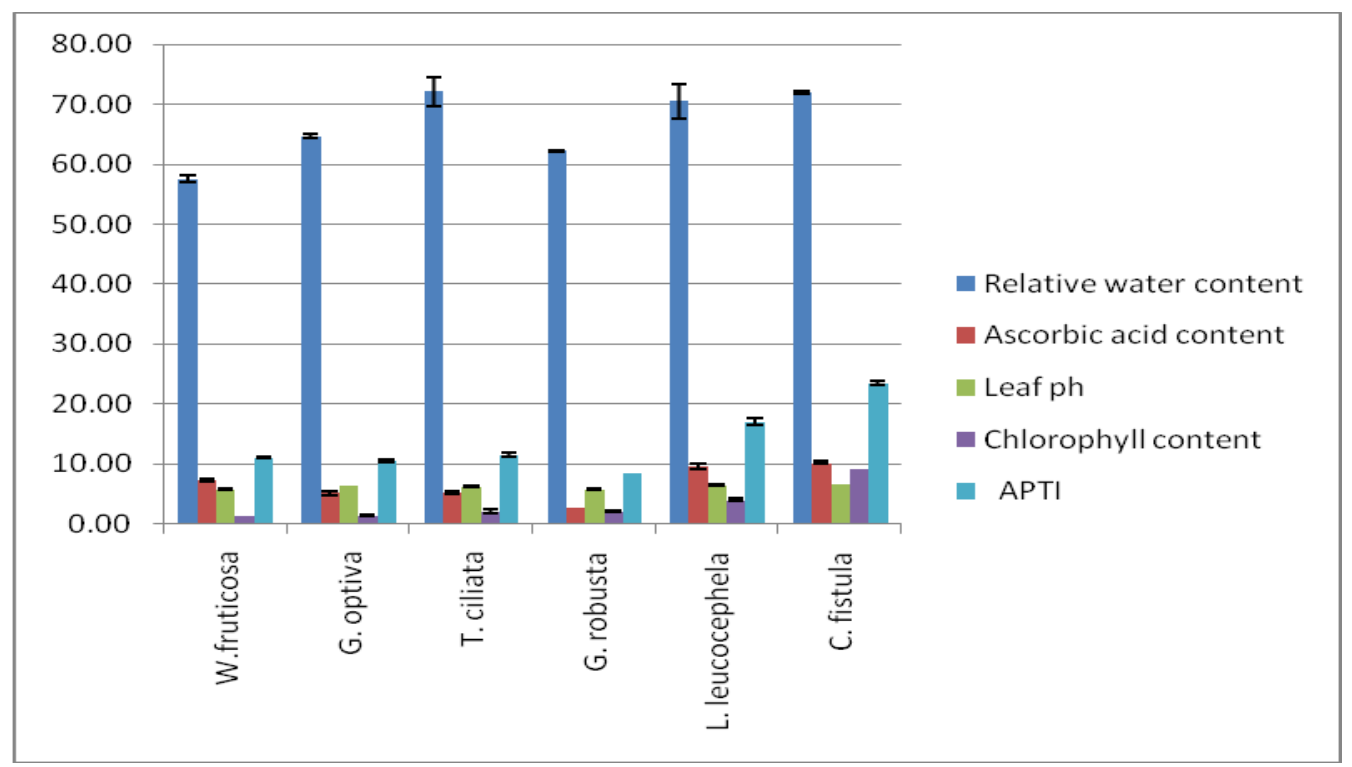




\section{Leaf relative water content}

The relative water content varied significantly among the different plant species growing along the National Highway -22 . The relative water content of selected plant species varied from $72.07-57.58 \%$ (Fig. 1). Among the six selected species Toona ciliate was found to have maximum $(72.07 \%)$ relative water content while the minimum of $57.58 \%$ was observed in Woodfordia fruticosa. The order of relative water content in the leaves of selected plant species was Toona ciliate > Cassia fistula> Leuceana leucocephala > Grewia optiva> Grewiallia robusta> Woodfordia fruticosa with the respective values of $72.07 \%, 72.02 \%, 70.47 \%, 64.65 \%$, $62.27 \%, 57.58 \%$. The variation in RWC in plants may be due to difference in plants species (Nwadinigwe, 2014). The leaf relative water content is the amount of moisture a plant holds and is an indicator of hydration condition in the leaf matrix. The highest value of relative water content in Toona cilata may be ascribed due to its higher resistant capacity to stress conditions and maintenance of relative water content under polluted conditions by the plant may determine its relative tolerance to pollution (Verma, 2003; Gholami et al., 2016). Plants at polluted site absorbed more water this could be a physiological mechanism of the plants to withstand the effect of pollution in its environment (Tanee et al., 2014). The trend of higher RWC in the plants growing alongside the National Highway may be ascribed to relatively lower rate of transpiration at polluted sites which might have resulted in the leaves of the plants. The results are in line with Bora and Joshi (2014).

\section{Air pollution tolerance index}

The plant growing alongside the National Highway-22 varied significantly in their tolerance levels. Among the selected species the highest APTI of 23.50 was recorded for Cassia fistula which was followed by Leuceana leucocephala (17.10), Toona ciliata (11.61), Woodfordia fruticosa (11.04), Grewia optiva (10.50) while the lowest value of 8.50 was noted in Grewiallia robusta. Fig.1. The variation in the tolerance of the trees of a region to air pollution has also been reported by Lakshmi et al., (2008); Agbaire and Esiefarienrhe (2009). The higher value of APTI in Cassia fistula may be due to increased production of ascorbic acid and higher relative water content during pollution stress (Kuddus et al., 2011). The highest APTI of the plants near the highway may be ascribed to the reason that the trees in order to adapt the stress due to auto exhaust pollution improve their tolerance capacity. Tolerance to air pollution alters from species to species depending on plants capacity to endure the effect of pollutants (Gholami et al., 2016). The higher APTI adjacent to National Highway showed higher tolerance of plant species to air pollutants (Jyothi and Jaya, 2010). It has been reported that tolerance of plant towards air pollutants is specific to a site and depends on the type and level of pollution (Noor et al., 2015).

\section{Anticipated performance index}

API is used as an indicator to assess the capability of predominant species for the abatement of the atmospheric pollutants and in green belt development. The anticipated performance index calculated by evaluation and grading of tree species based on their APTI and some biological and socioeconomic characters showed a variation from not recommended category to the category good. The highest values of API (4) were calculated in Cassia fistula and Toona ciliata and were considered as Good for Green belt development and Leuceana leucocephala, Grewia optiva and Grewiallia robusta with API value of (2) were assessed as poor 
whereas Woodfordia with APII value of zero was assessed as not recommended Table.4. The highest API of Cassia fistula may be due to its high APTI. API value is more for the species with higher APTI having better plant and leaf characteristics (Prajapati and Tripathi, 2008). Among all the plant species Cassia fistula was the most tolerant species and also this species has the high economic and aesthetic value. Hence it can be recommended for the plantation in the polluted areas. From the present investigation it can be concluded that all the biochemical, physiological, biological as well as socioeconomic parameters of the plant species play an important role in determining the sensitivity and tolerance of plants to air pollution with reference to their tolerance and performance index. The study indicated that Cassia fistula should be considered for plantation alongside the National Highway 22 because of its highest tolerance capacity to pollution and high anticipated performance index among the commonly growing species. Tsega and Deviprasad (2014) also concluded that plant species with high API values should be recommended for establishment of the green belts.

\section{Acknowledgment}

The author is thankful to the Department of Environmental Sciences, Dr. Y.S Parmar UHF, Nauni, Solan for providing necessary facilities and sincere gratitude is expressed to Dean College of Forestry for providing financial support to conduct the study.

\section{References}

A. O. A. C. 1980. Official methods of analysis of the analytical chemist, 13th ed. (W. Horwitz, ed.). Association of Analytical Chemists. 83: 617-623.

Agbaire, P. O. and Esiefarienrhe, E. 2009. Air Pollution Tolerance Indices (APTI) of some plants around Otorogun gas plant in Delta state, Nigeria. J. Applied Sci. Environ. Manage. 13(1): 11-14.

Barrs, H. D. and Weatherly, P. E. 1962. A reexamination of the relative turbidity technique for estimating water deficit in leaves. Australian Journal of Biological Sciences. 15: 413-42.

Begum, A. and Harikrishna, S. 2010. Evaluation of some tree species to absorb air pollutants in three industrial locations of South Bengaluru, India. Journal of Chemistry. 7(1): 151-156.

Bhattacharya, T., Kriplani, L., and Chakraborty, S., 2013. Seasonal Variation in Air Tolerance Index of Various Plant Species of Baroda City, Universal Journal of Environmental Research and Technology. 3(2): 199208.

Bora Meha and Joshi Namita. 2014. A study on variation in biochemical aspects of different tree species with tolerance and performance index. The Bioscan 9(1): 59-63.

Cheng F. Y., Burkey K. O., Robinson J. M. and Booker F. L. 2007. Leaf extracellular ascorbic in relation to $\mathrm{O}_{3}$ tolerance of two soybean cultivars. Environmental Pollution 150: 355-362

Gholami, A., Mojiri, A. and Amini, H. 2016. Investigation of the air pollution tolerance index using some plant species in Avhaz region. Journal of Animal and Plant Sciences. 26 (2): 475480.

Govindaraju, M., Ganeshkumar, R. S., Muthukumaran, V. R. and Visvanathan, P. 2012. Identification and evaluation of air pollution tolerant plants around lignite-based thermal power station for greenbelt development. Environmental Science and Pollution Research. 19 (4): 1210-1223.

Hiscox, J. D. and Israelstam G. F. 1979. A method for the extraction of chlorophyll 
from leaf tissue without maceration. Canadian Journal of Botany. 57: 13321334.

Joshi U. N., Rathore S. S and Arora S. K. 1993. Effect of chromium on growth and development of cowpea (Vigna unguiculata L). Indian Journal of Environment Protection. 19: 745-749

Jyothi, J. S. and Jaya, D. S. 2010. Evaluation of air pollution tolerance index of selected plant species along roadsides in Thiruvanthapuram, Kerala. Journal of Environmental Biology. 31: 379-386.

Kaur, M. and Nagpal, A.K., 2017. Evaluation of air pollution tolerance index and anticipated performance index of plants and their application in development of green space along the urban areas. Environmental Science and Pollution Research. 24(23): 18881-18895.

Kuddus, M., Kumari, R. and Ramteke, P. W. 2011. Studies on air pollution tolerance of selected plants in Allahabad city, India. J. Environmental Research and Management. 2(3): 042-046.

Lakshmi, P. S., Sravanti, K. L. and Srinivas, L. 2008. Air pollution tolerance index of various plant species growing in industrial areas. The Ecoscan. 2(2): 203-206.

Madan, S. and Chauhan, S. 2015. Air pollution tolerance index and anticipated performance index of selected plant species in Haridwar City, India. Report and Opinion. 7 (6): 32-37.

Mahecha G.S., Bamniya, B.R., Nair, Neelima and Saini D. 2013. Air pollution tolerance index of certain plant speciesA study of Madri Industrial Area, Udaipur (Raj.), India, Int. J. Innovative Res. Sci. Engg. Tech. 2(12): 7927-7929.

Mir, Q. A. 2008. Vehicular pollution and pigment content of certain avenue trees. Poll. Res. 27: 59-63. Mir QA, Yazdani T, Kumar A, Narain K, Yunus M. Vehicular population and pigment content of certain avenue trees. Pollut Res 2008; 27: 59-63.

Mondal, D., Gupta, S. and Kumar, J.D. 2011. Anticipated performance index of some tree species considered for green belt development in an urban area. International Research Journal of Plant Science. 2(4): 99-106

Ninave, S. Y. 2001. Biochemical features of plants as indicators of air pollution. Bulletin of Environmental Contamination and Toxicology. 67(1): 133-140.

Noor, M. J., Sultana, S., Fatima, S., Ahmad, M., Zafar, M., Sarfraz, M., Balkhyour, M. A., Safi, S. Z. and Ashraf, M. A. 2015. Estimation of Anticipated Performance Index and Air Pollution Tolerance Index of vegetation around the marble industrial areas of Potwar region: bioindicators of plant pollution response. Environmental Geochemistry and Health. 37(3): 441-455.

Nwadinigwe, A. O. 2014. Air pollution tolerance indices of some plants around Ama industrial complex in Enugu State, Nigeria. African Journal of Biotechnology. 13(11): 1231-1236.

Prajapati, S. K. and Tripathi, B.D. 2008. Seasonal variation of leaf dust accumulation and pigment content in plant species exposed to urban particulates pollution. Journal of Environmental Quality. 36: 704-705.

Shannigrahi, A. S., Sharma, R. C. and Fukushima, T. 2003. Air pollutioncontrol by optimal green belt development for Victoria Memorial Monument, Kolkata (India). Intern. J. Environ. Studies. 60(3): 241-249.

Singare, P.U. and Talpade, M. S. 2013. Physiological responses of some plant species as a bio indicator of roadside automobile pollution stress using the air pollution tolerance index approach. 
International Journal of Plant Research 3(2): 9-16

Singh, A. 1977. Practical Plant Physiology. Kalyari Publishers. New Delhi

Singh, S. K and Rao, D. N.1983. Evaluation of the plants for their tolerance to air pollution. Proceeding in: Symposium on Air Pollution control held at IIT, Delhi. pp. 218-224

Subramani, S. and Devaanandan, S. 2015. Application of air pollution tolerance index in assessing the air quality. International Journal of Pharmacy and Pharmaceutical Sciences. 7(7): 216221.

Tanee, F. B. G., Albert, E. and Amadi, B.R. 2014. Biochemical properties and Air pollution tolerance indices of plants in Port Harcourt city, Nigeria. British
Journal of Applied Science and Technology. 4 (34): 4835-4845.

Tsega, Y. C. and Deviprasad, A.G. 2014. Variation in air pollution tolerance index and anticipated performance index of roadside plants in Mysore, India. Journal of Experimental Biology. 35: 185-190.

Verma, A. 2003. Attenuation of automobile generated air pollution by higher plants. Dissertation, University of Lucknow (unpublished).

Yannawar, V. B. and Bhosle, A. B. 2013. Air pollution tolerance index of various plant species around Nanded city, Maharastra, India. J. Applied Phytotechnology in Environmental Sanitation. 3(1): 23-28

\section{How to cite this article:}

Kashish Walia, R.K. Aggrawal and Bhardwaj, S.K. 2019. Evaluation of Air Pollution Tolerance Index and Anticipated Performance Index of Plants and their Role in Development of Green Belt along National Highway-22. Int.J.Curr.Microbiol.App.Sci. 8(03): 2498-2508. doi: https://doi.org/10.20546/ijcmas.2019.803.296 